\title{
PERAN PROGRAM PEMBERDAYAAN MASYARAKAT DESA DALAM PEMBANGUNAN PEDESAAN
}

\author{
Drs. Almasri, M.Si \\ Devi Deswimar, S.Sos, M.Si \\ Dosen Fakultas Ekonomi dan Ilmu Sosial \\ Universitas Islam Negeri Sultan Syarif Kasim Riau
}

\begin{abstract}
Abstrak
Pembangunan masyarakat pedesaan merupakan bagian penting dari perwujudan pembangunan otonomi daerah dalam rangka pemerataan pembangunan dan kesejahteraan masyarakat. Salah satu upaya yang dilakukan pemerintah adalah meningkatkan keikutsertaan masyarakat desa dengan membuat program-program nasional yang salah satunya adalah program pemberdayaan masayarakat desa. Seperti yang kita ketahui, masayarakat pedesaan adalah masyarakat yang identik dengan kemisikinan dan keterletarbelakangan padahal tidak sedikit potensi yang dimiliki oleh mayarakat desa. Upaya penanggulangan kemiskinan yang paling strategis dalam era otonomi daerah dapat dirumuskan dalam satu kalimat yaitu "berikan peluang kepada keluarga miskin dan komunitasnya untuk mengatasi masalah mereka secara mandiri". Ini berarti pihak luar harus mereposisi peran mereka, dari agen pemberdayaan menjadi fasilitator pemberdayaan. Input yang berasal dari luar yang masuk dalam proses pemberdayaan harus mengacu sepenuhnya pada kebutuhan dan desain aksi yang dibuat oleh keluarga miskin itu sendiri bersama komunitasnya melalui proses dialog yang produktif agar sesuai dengan konteks setempat.Artinya program pemberdayaan masyarakat desa adalah program yang sangat mementingkan kebutuhan masyarakat pedesaan.
\end{abstract}

Kata Kunci : Pemberdayaan, Otonomi Daerah, Masyarakat Pedesaan

\section{PENDAHULUAN}

\section{Latar Belakang}

Pembangunan nasional dan daerah merupakan bagian yang tidak dapat dipisahkan dari kegiatan pembangunan desa, mengingat kosentrasi jumlah penduduk masih dominan berada di daerah desa, sehingga desa merupakan basis kekuatan sosial ekonomi dan politik yang perlu mendapat perhatian serius dari pemerintah. Perencanaan pembangunan selama ini lebih bersifat "top down"dibandingkan "bottom-up", sehingga telah menjadikan masyarakat desa sebagai objek pembangunan semata, bukan sebagai subjek pembangunan.
Sejak diberlakukannya UU No. 32 Tahun 2004 tentang Pemerintahan Daerah, setiap daerah diberi keleluasaan untuk menekankan prinsip-prinsip demokrasi, peran serta masyarakat, pemerataan, keadilan serta dengan memperhatikan potensi dan keanekaragaman daerah. UU ini sebagai landasan hukum bagi tiap daerah untuk mengatur dan mengurus kepentingan masyarakat setempat menurut prakarsa sendiri berdasarkan aspirasi masyarakat. Masyarakat diberi peran yang lebih besar dalam pembangunan daerah. Selain itu masyarakat dituntut berkreativitas dan berinovasi dalam mengelola potensi daerah 
serta memprakarsai pembangunan daerah. Sejalan dengan perkembangan kemampuan rakyat dalam pembangunan dan berkurangnya campur tangan pemerintah pusat terhadap daerah, maka pembangunan seharusnya diarahkan untuk merubah kehidupan rakyat menjadi lebih baik. Perencanaan dan implementasi pembangunan seharusnya merupakan usaha untuk memberdayakan rakyat sehingga mereka mempunyai akses terhadap sumber-sumber ekonomi.

Tujuan utama dari pembangunan yang dilaksanakan oleh pemerintah adalah untuk meningkatkan taraf hidup masyarakatnya. Berbagai usaha dari berbagai sektor terus dikembangkan dalam usaha pencapaian tujuan tersebut.

Secara historis desa merupakan cikal bakal terbentuknya masyarakat politik dan pemerintahan di indonesia jauh sebelum negara-bangsa ini terbentuk. Namun sekarang ini pembangunan di tingkat desa masih jauh dari harapan karena lambannya pembangunan yang terjadi di tingkat desa tersebut. Kondisi ini terjadi bisa saja karena jauhnya jangkauan menuju desa tersebut ataupun sulitnya akses menuju desa tersebut.

Pemberdayaan masyarakat adalah upaya untuk meningkatkan daya atau kekuatan pada masyarakat dengan cara memberi dorongan, peluang, kesempatan, dan perlindungan dengan tidak mengatur dan mengendalikan kegiatan masyarakat yang diberdayakan untuk mengembangkan potensinya sehingga masyarakat tersebut dapat meningkatkan kemampuan dan mengaktualisasikan diri atau berpartisipasi melalui berbagai aktivitas. Pemberdayaan Masyarakat pada dasarnya adalah suatu proses pertumbuhan dan perkembangan kekuatan masyarakat untuk ikut terlibat dalam berbagai aspek pembangunan di suatu wilayah. Dengan adanya pemberdayaan bisa melepaskan masyarakat dari keterbelakangan dan kemiskinan, sehingga masyarakat mampu bersaing dengan dunia luar.

Upaya-upaya untuk meningkatkan kesejahteraan rakyat Indonesia telah dilakukan sejak awal kemerdekaan. Misalnya, di bidang pendidikan, pemerintah melancarkan pemberantasan buta huruf tak terbatas di sekolah formal saja, namun juga secara non-formal. Di era Bung Karno, anakanak usia sekolah bahkan "dikejar" agar mau masuk sekolah. Di era Pak Harto, dicanangkan wajib belajar sembilan tahun, dan hasilnya luar biasa.

Di bidang kesehatan, pemerintah meluncurkan berbagai upaya untuk meningkatkan kualitas sumber daya manusia Indonesia dan memperkenalkan sistem santunan sosial. Di era Orde Baru, sejak 1970-an, dikenalkan pusat pelayanan kesehatan di tingkat kecamatan (Puskesmas) agar lebih mudah terjangkau oleh masyarakat desa. Belakangan dibentuk Pos Pelayanan Terpadu (Posyandu) di setiap desa. Pada awal 1990-an pembangunan pusat kesehatan masyarakat meningkat lebih tinggi daripada rumah sakit. Penempatan bidan di desa yang mendidik kader-kader dari kalangan penduduk desa sendiri, dan mendampingi kader dalam kegiatan rutin posyandu, menunjukkan upaya-upaya pemberdayaan masyarakat.

Melalui program transmigrasi, penduduk miskin dari daerah padat diberi peluang yang lebih baik untuk meningkatkan kesejahteraan ekonominya. Pembukaan dan pengembangan tanah pertanian baru diharapkan dapat meningkatkan kesempatan kerja para transmigran.

Dalam rangka penanggulangan kemiskinan pula diluncurkan berbagai Inpres, seperti Inpres Kesehatan, Inpres Perhubungan, Inpres Pasar, Bangdes, dan yang agak belakangan namun cukup terkenal adalah Inpres Desa Tertinggal (IDT). Dapat dicatat juga program-program pemberdayaan lainnya mulai dari era orde baru sampai era 
reformasi seperti Program Pembinaan dan Peningkatan Pendapatan Petani dan Nelayan Kecil (P4K), Program Tabungan dan Kredit Usaha Kesejahteraan Rakyat (TakesraKukesra), Program Pengembangan Kecamatan (PPK), Program Penanggulangan Kemiskinan Perkotaan (P2KP), Program Pembangunan Prasarana Pendukung Desa Tertinggal (P3DT), bahkan pengambangan program pemberdayaan masyarakat selanjutnya adalah PNPM-Mandiri, KAT, PANSIMAS dan seterusnya.

Upaya- upaya uang dilakukan pemerintah dalam pemberdayaan masyarakat semata-mata bertujuan untuk meningkatkan taraf hidup dan kesejahteraan masyarakat terutama masyarakat pedesaaan dan mengeluarkan masyarakat Indonesia dari belenggu kemiskinan dan ketidakberdayaan.

\section{Permasalahan}

Berdasarkan latar belakang, maka penulis menggangkat permasalahan yang akan dibahas adalah bagaimana peran program pemberdayaan masyarakat dalam pembangunan masyarakat pedesaan.

\section{Tujuan}

Adapun tujuan penelitian ini adalah untuk mengetahui peran program pemberdayaan masyarakat dalam pembangunan masyarakat pedesaan.

\section{PEMBAHASAN}

\section{Pengertian Otonomi Daerah}

Berdasarkan Kamus Besar Indonesia (2008: 992), otonomi adalah pola pemerintahan sendiri. Sedangkan otonomi daerah adalah hak, wewenang dan kewajiban daerah untuk mengatur dan mengurus rumah tangganya sendiri sesuai dengan peraturan perundang-undangan yang berlaku.

Otonomi daerah adalah perwujudan dari pelaksanaan urusan pemerintah berdasarkan asas desentralisasi yakni penyerahan urusan pemerintahan kepada daerah untuk mengurus rumah tangganya. Menurut Ahmad Yani (2002) salah satu urusan yang diserahkan kepada daerah adalah mengenai urusan yang memberikan penghasilan kepada pemerintah daerah dan potensial untuk dikembangkan dalam penggalian sumber-sumber pendapatan baru bagi daerah bersangkutan karena PAD ini sangat diharapkan dapat membiayai pengeluaran rutin daerah.

Menurut UU No. 32 Tahun 2004 tentang Pemerintahan Daerah Pasal 1 ayat 5 "tonomi daerah adalah hak, wewenang, dan kewajiban daerah otonom untuk mengatur dan mengurus sendiri urusan pemerintahan dan kepentingan masyarakat setempat sesuai dengan peraturan perundang-unndangan".

Sedangkan menurut Encyclopedia of Social Science dalam Ahmad Yani (2002: 5) pengertiannya yang orisinil, otonomi adalah The legal self suffiency of social body and its actual independence.

Otonomi daerah adalah hak penduduk yang tinggal dalam suatu daerah untuk mengatur, mengurus, mengendalikan dan mengembangkan urusannyasendiri dengan menghormati peraturan perundangan yang berlaku (Hanif Nurcholis, 2007; 30). Undangundang No. 32 Tahun 2004 sebagaimana telah diamandemen dengan Undang-undang N0. 12 Tahun 2008 tentang Pemerintahan Daerah juga mendefinisikan daerah otonom sebagai berikut : " Daerah Otonom, selanjutnya disebut daerah, adalah kesatuan masyarakat hokum yang mempunyai batasabatas wilayah 12 yang berwenang mengatur dan mengurus urusan pemerintah dan kepentingan masyarakat setempat menurut prakarsa sendiri bersasarkan aspirasi masyrakat dalam system Negara Kesatuan Republik Indonesia”.

\section{Pemerintahan Desa}

Istilah Desa secara etimologi berasal dari kata swadesi bahasa sansekerta yang 
berarti wilayah, tempat atau bagian yang mandiri dan otonom. Desa dapat didefinisikan sebagai kesatuan masyarakat hukum yang memiliki batas-batas wilayah yang berwenang untuk mengatur dan mengurus kepentingan masyarakat setempat, berdasarkan asal usul, adat istiadat setempat yang diakui dan dihormati dalam sistem pemeritnahan NKRI (Syafrudin dan Na'a, 2010:3).

Berdasarkan Undang-undang Nomor 32 Tahun 2004 Desa adalah atau yang disebut dengan nama lain, selanjutnya disebut desa, adalah kesatuan masyarakat hukum yang memiliki batas-batas wilayah yurisdiksi, berwenang untuk mengatur dan mengurus kepentingan masyarakat setempat berdasarkan asal-usul dan adat istiadat setempat yang di akui dan/atau dibentuk dalam sistem Pemerintahan Nasional dan berada di kabupaten/kota.

Dari uraian tentang desa diatas, desa adalah kumpulan masyarakat hukum dan merupakan organisasi terendah dibawah Kecamatan yang mempunyai kewenangan untuk mengatur rumah tangganya dan mengurus kepentingan masyarakat setempat berdasarkan hukum dan adat istiadat setempat. Desa merupakan organisasi yang berdiri sendiri dengan tradisi, adat istiadat dan hukumnya sendiri serta mandiri.

\section{Pemerintahan Desa}

Govelment is the organization of men under authority ...... how men can be governe, "Pemerintahan itu adalah sebagai suatu organisasi dari orang-orang yang mempunyai kekuasaaan ...... bagaimana mana manusia itu diperitnah" (R.Mac. Iver dalam Syafi'i 2002,13).

Pemerintahan Desa secara historis dibentuk oleh masyarakat desa dengan memilih beberapa orang anggota masyarakat yang dipercaya dapat mengatur, menata, melayani, memelihara dan melindungi berbagai aspek kehidupan mereka
(Awang,2010:60). Widjaja (2010:27) menjabarkan Kepmendagri No. 64 Tahun 1999 menyatakan bahwa pemerintahan desa adalah kegiatan pemerintahan yang dilaksanakan oleh pemerintahan desa BPD.

Menurut soemanti Pemerintahan Desa terdiri dari Kepala Desa dan Perangkat Desa, sedangkan Perangkat Desa terdiri dari Sekretaris Desa dan Perangkat lainnya, yaitu sekretariat desa, pelaksanaan teknis lapangan dan unsur kewilayahan, yang jumlahnya disesuaikan dengan kebutuhan dan kondisi sosial budaya setempat (Soemantri,2010:7).

Dari uraian diatas jelas sekali bahwa pemerintahan desa terdiri dari Kepala Desa dan perangkat desa lainnya yang dipercaya oleh masyarakat untuk mengatur, menata, melayani, memelihara dan melindungi berbagai aspek kehidupan masyarakat.

\section{Pembangunan Desa}

Menurut Ali Hanapiah Muhi (2011:4) Pembangunan desa pada hakikatnya adalah segala bentuk aktivitas manusia (masyarakat dan pemerintah) di desa dalam membangun diri, keluarga, masyarakat dan lingkungan di wilayah desa baik yang bersifat fisik, ekonomi, sosial, budaya, politik, ketertiban, pertahanan dan keamanan, agama dan pemerintahan yang dilakukan secara terencana dan membawa dampak positif terhadap kemajuan desa. Dengan demikian, pembangunan desa sesungguhnya merupakan upaya-upaya sadar dari masyarakat dan pemerintah baik dengan menggunakan sumberdaya yang bersumber dari desa, bantuan pemerintah maupun bantuan organisasi-organisasi/lembaga domestik maupun internasional untuk menciptakan perubahan-perubahan ke arah yang lebih baik.

Berbicara tentang pembangunan desa terdapat dua aspek penting yang menjadi objek pembangunan. Menurut Ali Hanapiah Muhi (2011:4) secara umum, pembangunan desa meliputi dua aspek utama yaitu 
pembangunan desa dalam aspek fisik dan pembangunan dalam aspek pemberdayaan insani. Pembangunan desa dalam aspek fisik yaitu pembangunan yang objek utamanya dalam aspek fisik (sarana, prasarana dan manusia) di pedesaan seperti jalan desa, bangunan rumah, pemukiman, jembatan, bendungan, irigasi, sarana ibadah, pendidikan (hardware berupa sarana dan prasarana pendidikan, dan software berupa segala bentuk pengaturan, kurikulum dan metode pembelajaran), keolahragaan, dan sebagainya. Pembangunan dalam aspek fisik ini selanjutnya disebut pembangunan desa.

Pemberdayaan masyarakat menurut Widjaja (2005:169) adalah upaya meningkatkan kemampuan dan potensi yang dimiliki masyarakat sehingga masyarakat dapat mewujudkan jati diri, harkat dan martabatnya secara maksimal untuk bertahan dan mengembangkan diri secara mandiri baik dibidang ekonomi, sosial, agama dan budaya.

Selanjutnya Nurcholis (2011:104) menyatakan pelayanan pembangunan adalah pelayanan pemerintah desa dalam bentuk melakukan pembangunan yang berdampak pada peningkatan pendapatan warga desa baik langsung maupun tidak langsung. Menurut Widjaja (2005:95) setiap desa memiliki kondisi dan potensi yang khas berbeda dengan desa lainnya, demikian pula aspirasi dan karakter masyarakatnya oleh sebab itu pembangunan di desa memang sepatutnya lebih banyak ditentukan oleh masyarakat desa sendiri. Kedudukan pemerintah desa yang telah diberikan kewenangan penuh untuk memberdayakan masyarakatnya sudah tentu harus mempunyai kemampuan untuk mengurus rumah tangganya sendiri dengan lebih mengedepankan hak-hak masyarakat. Dengan demikian, kedudukan kepala desa lebih merupakan wakil dari pemerintah desa dan masyarakat desa itu sendiri daripada sebagai wakil pemerintah pusat, pemerintah provinsi, dan pemerintah kabupaten/kota.
Oleh karena itu menurut Ali Hanapiah Muhi (2011:8) pembangunan desa dalam aspek pembangunan fisik, pembangunan prasarana dan sarana di daerah pedesaan semestinya menempatkan penduduk atau masyarakat desa sebagai subjek pembangunan. Sebagai subjek pembangunan menunjukkan bahwa masyarakat daerah pedesaan berperan sebagai pelaku pembangunan. Sudah semestinya masyarakat sebagai pelaku pembangunan mengambil posisi untuk berperan secara aktif dalam proses pembangunan. Peran aktif masyarakat dapat diwujudkan dalam berbagai bentuk keterlibatan atau pelibatan masyarakat dalam proses pembangunan, apakah pada tahap pengkajian, perencanaan, pelaksanaan, pemeliharaan atau pada semua tahap proses pembangunan tersebut.

Keikutsertaan masyarakat dalam pembangunan merupakan suatu hal yang penting bagi keberhasilan suatu kegiatan pembangunan yang menuju kepada kehidupan sosial, ekonomi dan politik masyarakat yang lebih baik. Wang (dalam Awang, 2006:61) mendefenisikan partisipasi sebagai proses kegiatan yang dilakukan oleh seorang ataupun oleh kelompok sebagai pernyataan kepentingan mereka untuk menyumbangkan tenaga dan sumber daya lainnya kepada institusi sosial dan sistem yang mengatur kehidupan mereka.

\section{Kemudian Awang}

(2006:62) menyatakan bahwa partisipasi masyarakat dalam pembangunan desa adalah keikutsertaan masyarakat dalam segala kegiatan mulai dari perencanaan, pelaksanaan, pemamfaatan sampai pemeliharaan dan pengawasan yang diselenggarakan di desa dengan cara memberikan sumbangan baik berbentuk materil seperti uang, barang dan tenaga, maupun dalam bentuk spiritual seperti pemikiran dan gagasan.

Selanjutnya berdasarkan Peraturan Mentri Dalam Negeri Nomor 66 tahun 
2007 tentang Perencanaan Pembangunan Desa, pembangunan di desa merupakan model pembangunan partisipatif adalah suatu sistem pengelolaan pembangunan di desa bersama-sama secara musyawarah, mufakat, dan gotong royong yang merupakan cara hidup masyarakat yang telah lama berakar budaya wilayah Indonesia. Sebagaimana disebutkan dalam pasal 5 Permendagri No 66 tahun 2007, karakteristik pembangunan partisipatif diantaranya direncanakan dengan pemberdayaan dan partisipatif. Pemberdayaan yaitu upaya untuk mewujudkan kemampuan dan kemandirian masyarakat dalam kehidupan bermasyarakat, berbangsa dan bernegara sedangkan partisipatif, yaitu keikutsertaan dan keterlibatan masyarakat secara aktif dalam proses pembangunan.

\section{Peran Program Pemberdayaan Masyarakat Pedesaan}

Pemberdayaan adalah pemberian wewenang, pendelegasiasn wewenang atau pemberian otonomi kejajaran bawah (Widjaja, 2011:77). Inti dari pemberdayaan upaya membangkitkan segala kemampuan yang ada untuk mencapai tujuan. Pencapaian tujuan melalui pertumbuhan motovasi, inisiatif, kreatif, serta penghargaan dan pengakuan bagi mereka yang berprestasi.

Stewart (dalam awang, 2010:46) mengatakan bahwa pemberdayaan adalah memberi kekuasaan, mengalihkan kekuatan atau mendelegasikan otoritas atau kewenangan kepada pihak lain atau memberi kemampuan dan keberdayaan.

Pemberdayaan yaitu upaya untuk mewujudkan kemampuan dan kemandirian masyarakat dalam kehidupan bermasyarakat, berbangsa dan bernegara (Soemantri,2010:74). Pemberdayaan adalah sebagian dari paradigma pembangunan yang memfokuskan perhatian kepada semua aspek yang prinsipil dari manusia di lingkungannya yakni mulai dari aspek intelektual (sumber daya manusia), aspek material dan fisik, sampai kepada aspek manajerial (Rahayu ,2008).

Prijono dan Pranarka (dalam awang, 2010:47) menyebutkan pemberdayaan sebagai proses belajar mengajar yang merupakan usaha terencana dan sistematis yang dilaksanakan secara berkesinambungan baik bagi individu maupun kolektif, guna mengembangkan daya (potensi), dan kemampuan yang terdapat dalam diri individu dan kelompok.

Berdasarkan uraian diatas Pemberdayaan merupakan sebuah proses menuju peningkatan kekuatan, kemampuan, serta menciptakan kemandirian masyarakat sehingga pontensi yang dimiliki masyarakat bisa berkembang dan masyarakat mampu bersaing dengan dengan dunia luar. Menurut Wadusistiono (2003:60) pemberdayaan adalah upaya membuat orang, kelompok atau masyarakat menajadi lebih berdaya, sehingga mampu mengurus kepentingannya secara mandiri. Upaya pemberdayaan masyarakat terus dilakukan oleh pemerintah, demi terwujudnya kemandirian masyarakat serta pembangunan terutama pembangunan di tingkat desa. Dalam memandirikan masyarakat serta mengembangkan potensi potensi yang dimiliki oleh masyarakat, masyarakat tidak hanya sebagai penerima hasil akan tetapi masyarakat haruslah ikut aktif dan berpartisipasi dalam kegiatan pembangunan, sehingga terwujudlah kemandirian dalam masyarakat tersebut.

Pemberdayaan diartikan sebagai upaya peningkatan profesionalisme dan kinerja pelaku pembangunan di daerah, termasuk aparatur, organisasi sosial kemasyarakatan, lembaga swadaya masyarakat dunia usaha dan anggota masyarakat untuk mengatasi berbagai masalah yang dihadapi serta merealisasikan aspirasi dan keragaman masyarakat untuk mewujudkan peningkatan kualitas hidup dan kesejahteraan masyarakat (Adisasmita, 2011:131). 
Masyarakat itu merupakan suatu kelompok orang-orang yang hidup dalam suatu lingkungan tertentu yang mempunyai tradisi institusi, aktivitas dan kepentingan bersama (Thoha, 2010:28). Selanjutnya Miriam Budiardjo mendefinisikan tentang masyarakat. Menurutnya masyarakat adalah keseluruhan antara hubungan-hubungan antarmanusia (Budiardjo, 2009:46).

Jadi masyarakat adalah sekumpulan orang-orang yang saling berhubungan dalam suatu lingkungan dan mempunyai kepentingan bersama. Selanjutnya Widjaja mendefinisikan pemberdayaan masyarakat. Pemberdayaan masyarakat adalah upaya peningkatan kemampuan dan potensi yang dimiliki masyarakat, sehingga masyarakat dapat mewujudkan jati diri, harkat dan martabatnya secara maksimal untuk bertahan dan mengembangkan diri secara baik dibidang ekonomi, sosial, agama dan budaya (Widjaja, 2010:169).

Upaya peningkatan kemampuan dan potensi masyarakat sangatlah penting, terutama bagi masyarakat desa. Dengan adanya peningkatan kemampuan dan potensi yang dimiliki masyarakat desa, mereka bisa bersaing dengan masyarakat lainnya, meningkatkan taraf hidup serta bsia mengembangkan kemampuan mereka secara baik di bidang ekonomi, sosial, agama dan budaya sehingga masyarakat desa tidak tertinggal jauh dari masyarakat kota yang lebih maju.

Menurut Soemantri pemberdayaan masyarakat memiliki makana bahwa penyelenggaraan pemerintahan dan pelaksana pembangunan di desa ditujukan untuk peningkatan taraf hidup dan kesejahteraan masyarakat melalui penerapan kebijakan, program dan kegiatan yang sesuai dengan esensi masalah dan prioritas kebutuan masyarakat (Soemantri, 2011:3).

Lebih lanjut Subejo dan Narimo (Dalam Mardikanto dan Soebianto, 2012:31) mengartikan proses pemberdayaan masyarakat merupakan upaya yang disengaja untuk memfasilitasi masyarakat lokal dalam merencanakan, memutuskan, dan mengelola sumberdaya lokal yang dimilki melalui collecitve action dan networking sehingga pada akhirnya memiliki kemampuan dan kemandirian secara ekonomi, ekologi dan sosial.

Dari uraian diatas kita melihat bahwa pentingnya pemberdayaan masyarakat terutama bagi masyarakat desa. Karna dengan begitu tingkat kesejahterahan masyarakat dan taraf hidup masyarakat desa diharapkan bisa lebih meningkat. Peningkatan taraf hidup dan kesejahteraan masyarakat desa bisa menjadi bukti bahwa masyarakat desa telah berkembang maju dari sebelumnya.

Program Pemberdayaan Masyarakat Desa adalah satu bentuk program penanggulangan kemiskinan sebagai upaya untuk menyelesaikan masalah rendahnya kesejahteraan rakyat yang merupakan kewajiban pemerintah sesuai agenda utama Pembangunan Nasional sebagaimana tertuang dalam Program Pembangunan Nasional (Propenas), serta dalam Keputusan Gubernur Riau Nomor 592/IX/2004.

Sesuai dengan semangat Otonomi Daerah, maka PPD lebih diarahkan untuk menumbuhkan rasa tanggung jawab bersama antara pemerintah dan masyarakat, tidak saja dalam hal pengendalian dan pembinaan, tetapi juga dalam hal pembiayaan program. Karena itu komitmen dari DPRD dan Pemerintah Daerah memiliki peran penting dalam pemberian dukungan dan pembiayaan PPD.

Dalam jangka panjang diharapkan prinsip-prinsip dan mekanisme PPD diterapkan dan diadopsi untuk programprogram pembangunan lainnya, khususnya dalam rangka penanggulangan kemiskinan.

Skenario yang ada dalam PPD selalu diarahkan pada penciptaan kondisi dan lingkungan yang memungkinkan masyarakat dapat menikmati kehidupan yang lebih baik 
dan sekaligus memberi kesempatan yang lebih luas kepada masyarakat untuk melakukan pilihan-pilihan secara bebas dan mandiri sesuai dengan potensi dan karakteristik yang mereka miliki.

Dalam Program Pemberdayaan Desa (PPD), upaya memperkuat faktor pendidikan ini dilakukan dengan memberikan informasi, melakukan transfer ilmu pengetahuan dan tehnologi, menumbuhkan pola pikir yang rasional, mendorong kesadaran berpartisipasi dalam pembangunan, sehingga dapat tertanam benih-benih "Modernisasi" dalam kehidupan masyarakat. Dengan demikian PPD akan menjadi wahana socio-cultural learning bagi masyarakat.

Dalam Program Pemberdayaan Desa (PPD) upaya memperkuat penguasaan masyarakat terhadap sumber-sumber ekonomi dilakukan dengan memberikan kesempatan kepada masyarakat untuk memilih kegiatan-kegiatan yang berkaitan dengan akses modal. Sebab bagi masyarakat golongan ekonomi lemah, beberapa sumber kemajuan ekonomi diatas masih merupakan barang langka dan merupakan kendala utama bagi keberdayaan mereka. Kecilnya modal, rendahnya penguasaan tehnologi, sempitnya peluang dan kesempatan kerja, terbatasnya pengembangan sumber daya manusia dan tidak dikuasainya akses pasar, sering menjadi penyebab utama ketergantungan dan ketertinggalan masyarakat lapisan bawah. Padahal berbagai faktor tersebut merupakan prasyarat keberdayaan yang mutlak diperlukan.

Upaya pengembangan potensi dan sumber daya masyarakat agar dapat bersaing secara adil dan tanpa ketergantungan, harus disertai dengan pemberian perlindungan dengan pemihakan terhadap mereka yang lebih lemah. Hal ini dimaksudkan agar tidak terjadi hukum rimba, dimana yang kuat akan selalu menang dan yang lemah selalu kalah, yang mengakibatkan pola hubungan antar kelompok yang tidak setara dan tidak adil di masyarakat. Pemberian perlindungan (proteksi) ini dimaksudkan agar mereka yang lemah itu tidak semakin lemah, tetapi justru mampu bersaing secara seimbang, serta menciptakan kebersamaan dan kemitraan antara yang sudah maju dengan yang belum berkembang.

Salah satu agenda utama Pembangunan Nasional sebagaimana tertuang dalam Program Pembangunan Nasional (Propenas) 2000-2004 adalah menyelesaikan masalah rendahnya kesejahteraan rakyat.

Menurut Program Pembangunan Nasional (Propenas) 2000-2004, prioritas Program Pembangunan Nasional diarahkan pada upaya-upaya :

a. Penanggulangan kemiskinan dan pemenuhan kebutuhan dasar rakyat,

b. Merangsang pertumbuhan usaha kecil, menengah dan koperasi,

c. Penciptaan stabilitas ekonomi dan moneter,

d. Peningkatan daya saing,

e. Peningkatan investasi,

f. Penyediaan prasarana untuk mendukung pengembangan ekonomi,

g. Pemanfaatan sumber daya alam secara berkelanjutan.

Dari upaya-upaya yang dilakukan ini diharapkan masyarakat terus di stimulasi dan dikuatkan untuk dapat mengorganisir diri, termasuk menentukan sendiri kegiatan pembangunan daerahnya secara musyawarah sesuai dengan kebutuhannya. Dalam pelaksanaannya tetap mengacu kepada azas : Dari, Oleh dan Untuk Masyarakat (DOUM).

Dalam rangka otonomi daerah dan desentralisasi maka perlu dikembangkan sebagai media untuk membangun kesadaran masyarakat dan semua pihak terhadap perubahan arah dan nafas pembangunan. Program Pemberdayaan Desa/Kelurahan (PPD) merupakan media pembelajaran dan pengembangan kemampuan para pelaku pembangunan, serta media mewujudkan masyarakat sebagai penggagas dalam sebuah 
kegiatan pembangunan. Pengembangan konsep PPD ini juga diarahkan kepada penyelenggaraan Pemerintah yang baik (Good Governance). Beberapa proses dan kegiatan yang dilaksanakan dalam PPD selalu mempertimbangkan agar dapat mendukung pencapaian pemerintahan yang baik.

Seluruh proses kegiatan dalam PPD memiliki tiga dimensi yaitu:

a. Memberikan wewenang dan kepercayaan kepada masyarakat untuk menentukan sendiri kebutuhannya, merencanakan dan mengambil keputusan secara terbuka dan penuh tanggung jawab,

b. Menyediakan dukungan lingkungan yang kondusif untuk mewujudkan peran masyarakat dalam pembangunan, khususnya dalam upaya peningkatan kesejahteraan mereka sendiri,

c. Menyediakan Dana Usaha Desa untuk mendanai kegiatan ekonomi masyarakat desa.

Hal ini diperkuat dengan komitmen untuk mengentaskan kemiskinan dan mempercepat pemecahan masalah kemiskinan yang dituangkan melalui :

a. Keputusan Presiden Nomor 124 Tahun 2001 Tentang Pembentukan Komite Penanggulangan Kemiskinan, yang diperkuat dengan Keppres Nomor 8 Tahun 2002.

b. Keputusan Gubernur Nomor 592/IX/2004 Tentang Pembentukan Komite Penanggulangan Kemiskinan Propinsi Riau.

Program Pemberdayaan Desa akan dilaksanakan selama 5 (Lima) tahun pada setiap desa/kelurahan, dengan pola sebagai berikut :

a. Masa Pembinaan.

Masa pembinaan dilakukan dengan pola pendampingan selama 3 (Tiga) tahun, pada masa ini dilakukan kegiatan berupa penyediaan Dana Usaha Desa/ Kelurahan, pelatihan, pemenuhan kebutuhan sarana dan prasarana yang dibutuhkan oleh masyarakat, peningkatan partisipasi masyarakat dalam perencanaan, pelaksanaan serta pelestarian dan pengembangan hasil kegiatan.

b. Masa Transisi

Masa transisi dilakukan selama 2 (Dua) tahun untuk mencapai UED- SP Mandiri sebagai cikal bakal BUM-Des. Proses pembinaan dan monitoring tetap dilakukan secara berkala oleh Fasilitator Program dan Tim Koordinasi Provinsi dan Kabupaten/ Kota. Pada tahap ini dibangun kemandirian kelembagaan UED/K-SP dan kelembagaan desa lainnya.

Adapun Visi PPD adalah mewujudkan masyarakat riau yang sejahtera dan mandiri sesuai dengan Visi Riau 2020.

Adapunmisi PPD adalah:

a. Mempercepat penanggulangan kemiskinan melalui pengembangan ekonomi masyarakat dengan pemberian Dana Usaha Desa/Kelurahan,

b. Memperkuat kelembagaan masyarakat desa,

c. Mendorong pelembagaan sistem pembangunan partisipatif,

d. Mendorong peran aktif dinas sektoral untuk memenuhi kebutuhan dasar masyarakat desa/kelurahan.

Tujuan Program PPD adalah :

Tujuan Program Pemberdayaan Desa adalah mempercepat penanggulangan kemiskinan melalui pengembangan ekonomi masyarakat dengan pemberian Dana Usaha Desa/Kelurahan menuju kemandirian desa.

Program Pemberdayaan Desa menitik beratkan pada pemberdayaan masyarakat sebagai pendekatan operasional, merupakan wujud nyata komitmen Pemerintah Provinsi Riau untuk meningkatkan kesejahteraan masyarakat, melalui a. Perluasan kesempatan dan peluang bagi orang miskin dalam kegiatan ekonomi produktif dalam bentuk :

1. Penciptaan iklim pertumbuhan ekonomi yang berpihak kepada masyarakat miskin,

2. Penciptaan lapangan kerja, 
3. Penyediaan bantuan permodalan yang berpihak kepada masyarakat miskin.

4. Penguatan peran aparat pemerintah desa/kelurahan.

5. Pemberdayaan masyarakat melalui peningkatan kapasitas masyarakat dalam memanfaatkan sumber daya yang dimilikinya dalam bentuk

6. Penguatan kelembagaan masyarakat desa/kelurahan,

7. Mendorong partisipasi masyarakat dalam setiap kegiatan desa/kelurahan,

8. desa/kelurahan secara terencana dan berkelanjutan,

9. Penguatan kapasitas kelompok dan anggota usaha kecil dan menengah.

Untuk mendukung tercapainya tujuan program maka dalam pelaksanaannya harus sejalan dengan prinsip-prinsip dibawah ini :

a. Keberpihakan Kepada Orang Miskin

Setiap kegiatan yang dilaksanakan, baik dalam proses maupun pemanfaatan hasil kegiatan, harus mempertimbangkan manfaat yang sebesar-besarnya bagi kelompok orang miskin (bermanfaat lebih banyak bagi kelompok orang miskin).

b. Transparansi

Seluruh operasional kegiatan PPD harus dilakukan secara transparan (terbuka) dan diketahui oleh masyarakat luas. Dengan transparansi atau keterbukaan maka segala sesuatu yang dilakukan akan dapat dipertanggungjawabkan kepada masyarakat (accountable).

Dengan keterbukaan memudahkan masyarakat dalam :

1. Memperoleh informasi secara lengkap dan terus menerus tentang segala sesuatu yang menyangkut PPD,

2. Menumbuhkembangkan kepedulian dan partisipasi masyarakat dalam pelaksanaan pembangunan,

3. Mengawasi dan mengendalikan pelaksanaan PPD,

4. Meningkatkan saling percaya di antara sesama pelaku PPD. c. Partisipasi

Pengertian partisipasi dalam PPD adalah adanya keterlibatan masyarakat secara aktif terutama kelompok miskin dalam setiap tahap kegiatan PPD, mulai dari tahap sosialisasi, perencanaan, pelaksanaan, pengendalian, pelestarian dan pengembangan kegiatan

d. Desentralisasi

Desentralisasi bermakna sebagai pemberian kewenangan kepada masyarakat atau lebih mendasar adalah sejauh mana masyarakat memperoleh kembali hak-haknya yang otonom untuk mengelola pembangunan secara mandiri dan partisipasif.

Bentuk wewenang dan tanggungjawab masyarakat dalam PPD adalah :

1. Memanfaatkan dan mengelola Dana Usaha Desa/Kelurahan,

2. Memperoleh hak pendampingan,

3. Merencanakan dan melaksanakan kegiatan sesuai kebutuhannya,

4. Mempertanggungjawabkan pengelolaan Dana Usaha Desa/Kelurahan,

5. Memelihara dan melestarikan serta mengembangkan kegiatan yang telah dilaksanakan,

e. Kompetisi Sehat

Setiap pengambilan keputusan penting dalam PPD dilakukan melalui musyawarah dan bersifat kompetisi secara sehat untuk menentukan prioritas kegiatan yang didanai, berdasarkan hasil kajian atau telaah terhadap berbagai alternatif pilihan untuk mendapatkan pilihan terbaik.

Beberapa hal yang perlu diperhatikan untuk pengambilan keputusan dengan prinsip kompetisi sehat yaitu :

a. Mengutamakan alternatif atau pilihan terbaik terhadap sesuatu yang diputuskan berdasarkan kebutuhan dan atau persoalan yang ada di masyarakat

b. Menghindari setiap upaya dominasi dari individu tertentu demi kepentingan pribadi dan atau kelompok 
c. Mengutamakan keterlibatan masyarakat pada musyawarah mufakat dalam pembuatan keputusan

d. Unsur aparat dan Pendamping Desa/Fasilitator Program hanya bertindak sebagai fasilitator dalam setiap pengambilan keputusan di masyarakat.

\section{PENUTUP}

Kegiatan pembangunan nasional dengan segala ukuran keberhasilan dan dampak positif serta negatifnya, tidak terlepas dari kerja keras dan pengabdian aparat pemerintah desa. Meskipun demikian, masih banyak masalah yang dihadapi masyarakat desa yang sampai saat ini belum dapat diatasi secara tuntas, seperti masalah pengangguran, kemiskinan, ketimpangan distribusi pendapatan, ketidakseimbangan struktural ataupun keterbelakangan pendidikan.

Kenyataan ini telah membuktikan bahwa meskipun desa memiliki dua sumberdaya penting yaitu SDM dan SDA, tetapi kesatuan masyarakat hukum tersebut tidak mampu mengubah potensi yang dimilikinya menjadi sebuah kekuatan guna memenuhi kebutuhannya sendiri.

Pembangunan masyarakat pedesaan diartikan sebagai aktivitas yang dilakukan masyarakat dimana mereka mengidentifikasikan kebutuhan dan masalahnya secara bersama. Ada pula yang mengartikan bahwa pembangunan masyarakat desa adalah kegiatan yang terencana untuk menciptakan kondisi-kondisi bagi kemajuan sosial ekonomi masyarakat dengan meningkatkan partisipasi masyarakat. Pembangunan sektor sosial ekonomi masyarakat desa perlu diwujudkan untuk meningkatkan kesejahteran masyarakat yang didukung oleh organisasi dan partisipasi masyarakat yang terus menerus tumbuh dan berkembang dalam kehidupan masyarakat.

Konsentrasi pembangunan masyarakat yang diselenggarakan negara dapat mencurahkan perhatiannya pada kebijakan-kebijakan dan program-program pembangunan masyarakat, lembaga penyelenggara baik departemen, lintas departemen dan non departemen. Walaupun konsentrasinya berbeda, tetapi pada prinsipnya pembangunan masyarakat pada sektor apapun mengandung keempat unsur yang menjadi kerangka dasarnya yaitu sebagai proses perubahan, menciptakan hubungan serasi antara kebutuhan dan sumber daya, pengembangan kapasitas dan bersifat multidimensi.

Peran Program Pemberdayaan Desa/Kelurahan (PPD) merupakan media pembelajaran dan pengembangan kemampuan para pelaku pembangunan, serta media mewujudkan masyarakat sebagai penggagas dalam sebuah kegiatan pembangunan. Pengembangan konsep PPD ini juga diarahkan kepada penyelenggaraan Pemerintah yang baik (Good Governance). 


\section{DAFTAR PUSTAKA}

Adisasmita, Rahardjo. Manajemen Pemerintahan Daerah, Graha Ilmu, Yogyakarta; 2011

Awang, Azam. Implementasi Pemberdayaan Pemerintahan Desa. Pustaka Pelajar, Yogyakarta; 2010

Budiardjo, Miriam. Dasar-dasar Ilmu Politik. P.T Gramedia Pustaka Utama, Jakarta; 2009

Mardikanto, Totok dan Soebianto, Poerwoko. Pemberdayaan Masyarakat Dalam Perspektif Kebijakan Publik, C.V Alfabeta, Bandung; 2012

Nurcholis, Hanif. Pertumbuhan dan Penyelenggaraan Pemerintahan Desa. Erlangga, Jakarta;2011

Rahayu, Budiana. Pembangunan Perekonomian Nasional melalui Pemberdayaan Masyarakat Desa, MG, Semarang; 2008
Syafrudin, ateng dan Na'a, Suprin. Pergulatan Hukum Tradisional dan Hukum Moderen Dalam Desain Otonomi Desa. P.T. Alumni, Bandung; 2010

Syafiie, Inu Kencana. Sistem Pemerintahan Indonesia, P.T Rineka Cipta, Jakarta; 2002

Soemantri, Bambang Trisantoso. Pedoman Penyelenggaraan Pemerintahan Desa. Fokusmedia, Bandung; 2011

Thoha, Miftah. Birokrasi Politik di Indonesia, P.T Raja Grafindo Persada, Jakarta; 2010

Wasistiono, Sadu. Kapita Slekta Manajemen Pemerintahan Daerah, CV. Fokusmedia, Bandung; 2003

Widjaja, Haw. Otonomi Desa. P.T Raja Grafindo Persada, Jakarta; 2010

Widjaja, Haw. Otonomi Daeran dan Daerah Otonom. P.T Raja Grafindo Persada, Jakarta; 2011 